MaPan : Jurnal Matematika dan Pembelajaran

p-ISSN: 2354-6883 ; e-ISSN: 2581-172X

Volume 5, No 2, December 2017 (153-167)

DOI: https://doi.org/10.24252/mapan.v5n2a1

\title{
PENGARUH KECERDASAN INTRAPERSONAL TERHADAP PRESTASI BELAJAR MATEMATIKA SISWA DITINJAU DARI TINGKAT AKREDITASI SEKOLAH SMA NEGERI DI KABUPATEN POLEWALI MANDAR
}

\author{
Nurfadilah Mahmud1), Rezki Amaliyah AR2) \\ 1,2Universitas Sulawesi Barat \\ 1,2Kampus: Jl. Prof. Dr. Baharuddin Lopa, SH, Talumung, Majene, Sulawesi Barat \\ E-mail: ilamahmud.math@gmail.com ${ }^{1)}$, rezkiamaliyah@gmail.com²)
}

Submitted: 02-10-2017, Revised: 29-10-2017, Accepted: 17-11-2017

\begin{abstract}
Abstrak:
Penelitian ini bertujuan untuk mengetahui deskripsi kecerdasan intrapersonal dan pengaruh kecerdasan intrapersonal terhadap prestasi belajar matematika siswa kelas XI MIPA SMA Negeri di Kabupaten Polewali Mandar ditinjau dari tingkat akreditasi sekolah. Penelitian ini merupakan penelitian ex-post facto yang bersifat kausalitas. Penelitian ex-post facto dirancang untuk menerangkan adanya hubungan sebab akibat antar variabel kecerdasan intrapersonal dengan prestasi belajar matematika. Populasi dalam penelitian ini adalah seluruh siswa kelas XI MIPA SMA Negeri di Kabupaten Polewali Mandar tahun pelajaran 2016/2017. Sampel penelitian adalah 132 siswa yang diambil dengan menggunakan proporsional stratified random sampling. Instumen yang digunakan untuk pengumpulan data dalam penelitian ini adalah tes dan angket. Tes digunakan untuk memperoleh informasi mengenai prestasi belajar matematika, sedangkan angket digunakan untuk memperoleh informasi mengenai kecerdasan intrapersonal. Data dianalisis dengan statistika deskriptif dan analisis regresi linear sederhana. Hasil penelitian menunjukkan bahwa: (1) untuk sekolah dengan akreditasi A, B, dan tidak terakreditasi diperoleh kecerdasan intrapersonal dengan rata-rata skor 86,42 berada pada kategori tinggi dan prestasi belajar matematika dengan rata-rata skor 30,58 berada pada kategori kurang; (2) kecerdasan intrapersonal tidak berpengaruh terhadap prestasi belajar matematika pada sekolah dengan akreditasi A, $\mathrm{B}$, dan tidak terakreditasi.
\end{abstract}

Kata Kunci: Kecerdasan Intrapersonal, Prestasi Belajar Matematika

THE INFLUENCE OF INTRAPERSONAL INTELLIGENCE ON THE

MATHEMATICS LEARNING ACHIEVEMENT OF STUDENTS BASED ON
THE LEVELS OF SCHOOL ACCREDITATION OF STATE SMA IN
POLEWALI MANDAR DISTRICT

Abstract:

This research aimed to know description of intrapersonal intelligence and it's influence of intrapersonal intelligence to mathematic learning achievement of students in grade XI MIPA State SMA in Polewali based on the levels of school accreditation. This research was an ex post facto with causality study. Ex post facto study was designed to explain causal correlation 
between variable of intrapersonal intelligence and mathematics learning achievement. The Populations of this research were all of students in grade XI MIPA State SMA of Polewali Mandar in 2016/2017. Samples of the research were 132 student choosen by academic year using proporsional stratified random sampling. Instrument used to collect the data of this study were test and questionnaire. The test used to get information about mathematics learning achievement while questionnaire used to get information about intrapersonal intelligence. Datas were analyzed with descriptive statistic and simple linear regression analysis. Result of study shows that: (1) for schools with accredited A, B, and not accredited are obtained intrapersonal intelligence is in high category with mean score is 86,42 and mathematics learning achievement fall on low category. with mean score is 30,58; (2) intrapersonal intellgence is not effect on mathematics learning achievement of students in school with accreditation category of $A$ and $B$ also non accreditation.

Keywords: Intrapersonal Intelligence, Mathematics Learning Achievement

How to Cite: Mahmud, N. \& Amaliyah, R. A. R. (2017). Pengaruh Kecerdasan Intrapersonal terhadap Prestasi Belajar Matematika Siswa Ditinjau dari Tingkat Akreditasi Sekolah SMA Negeri di Kabupaten Polewali Mandar. MaPan : Jurnal Matematika dan Pembelajaran, 5 (2), 153-167.

$\mathrm{P}$ endidikan bertujuan untuk meningkatkan kecerdasan intelektual dan kemampuan akademik baik secara formal maupun informal dengan berbagai disiplin ilmu. Dari berbagai macam displin ilmu, matematika paling banyak dipilih oleh peserta didik sebagai pelajaran yang sulit dan tidak menyenangkan. Namun di sisi lain, matematika sangat penting untuk dipelajari karena tidak hanya melatih peserta didik untuk pandai menghitung dengan berbagai analisis, tapi juga melatih peserta didik untuk berfikir secara logis dan sistematis sehingga dapat diterapkan ketika mereka mulai terjun ke dunia kerja untuk memecahkan masalah, sebab kemampuan memecahkan masalah merupakan tujuan umum pengajaran matematika (Angriani, Bernard, Nur, \& Nurjawahirah, 2016).

Menteri Pendidikan dan Kebudayaan tahun 2015, Anies Baswedan mengatakan dalam artikel resmi dari mendikbud bahwa rerata nilai Ujian Nasional (UN) tahun 2015 untuk mata pelajaran Matematika khususnya program IPA mengalami penurunan dari 60,4 menjadi 59,17. Berdasarkan pernyataan tersebut menunjukkan bahwa secara umum kabupaten yang ada di Indonesia, nilai rerata mata pelajaran matematika untuk Program IPA mengalami penurunan termasuk Polewali Mandar. Selain itu, data yang diperoleh dari Lembaga Pengelola Dana Pendidikan (Lpdp, 2015) menunjukkan bahwa Kabupaten Polewali Mandar masih termasuk dalam 
daerah tertinggal sehingga dibutuhkan perhatian khusus dengan memberikan kontribusi dalam dunia pendidikan melalui kegiatan penelitian.

Berdasarkan wawancara dengan guru matematika SMA Negeri 1 Tinambung, diketahui bahwa siswa beranggapan bahwa matematika itu sulit dan hanya mengandalkan penjelasan dari guru untuk memahami materi, sehingga hasilnya adalah siswa terkesan santai dan tidak ada usaha untuk mencari tambahan ilmu matematika yang mungkin tidak didapatkan dari guru karena waktu yang terbatas. Selain itu, selama pembelajaran berlangsung, hanya 2 sampai 5 siswa saja yang aktif di kelas dan selebihnya menjadi siswa yang pasif. Anggapan siswa bahwa matematika itu sulit bukan tanpa alasan, hal ini dikarenakan persepsi awal siswa terhadap matematika adalah susah, membuat pusing kepala, bingung dengan analisis, terlebih lagi berbicara tentang logika sehingga dampaknya adalah prestasi belajar matematika yang menurun. Di sisi lain, seorang guru tidak dapat memaksakan kepada siswa untuk berfikir positif terhadap matematika. Tantangan bagi seorang guru adalah mampu memahami karakter dan tingkat intelektual masing-masing siswa.

Ada beberapa faktor yang mempengaruhi prestasi belajar siswa yang secara umum dibagi menjadi dua bagian yaitu faktor internal dan eksternal. Faktor internal merupakan segala kegiatan yang berpengaruh terhadap prestasi belajar matematika yang berasal dari dalam diri siswa, sedangkan faktor eksternal adalah segala kegiatan yang berdampak pada prestasi belajar matematika siswa yang berasal dari luar diri siswa. Kecerdasan intrapersonal adalah kemampuan siswa untuk mengenali diri sendiri dan bertindak untuk melakukan perbaikan berdasarkan kesadaran diri siswa (Aryadi, 2008), sehingga kecerdasan intrapersonal tergolong faktor internal. Jadi seorang siswa yang mempunyai kesadaran diri yang tinggi akan selalu berusaha mengembangkan kemampuannya meskipun dengan kondisi dari sarana dan prasana sekolah yang tidak mendukung (faktor eksternal). Oleh karena itu, yang menjadi fokus dalam penelitian ini adalah faktor internal khususnya faktor psikologi yaitu kecerdasan intrapersonal.

Menurut Gardner (Baharuddin, 2012: 147), kecerdasan intrapersonal merupakan kemampuan seseorang dalam memahami diri sendiri, mereka mempunyai kepekaan yang tinggi di dalam memahami suasana hatinya, emosi-emosi yang muncul di dalam dirinya dan menyadari perubahan yang terjadi dalam dirinya. Wikandaru (2011) juga menambahkan pendapatnya berdasarkan pandangan Gardner bahwa kecerdasan intrapersonal sebagai 
bagian dari kecerdasan majemuk (multiple intelligence) memerlukan kapasitas untuk memahami diri sendiri, untuk menghargai perasaan seseorang, ketakutan dan motivasi. Selain itu, kecerdasan intrapersonal melibatkan model kerja yang efektif dari diri kita sendiri, dan kemampuan untuk menggunakan informasi tersebut untuk mengatur kehidupan kita. Konselor, perencana, pekerja sosial, psikolog, penulis dan pemimpin agama perlu mengembangkan kecerdasan intrapersonal.

Dannenhoffer and Radin (Hidayati, Mardiana, \& Riyadi, 2014) menyatakan bahwa kecerdasan intrapersonal merupakan kemampuan untuk bertindak sesuai dengan pengetahuan sendiri, peka terhadap kekuatan dan kelemahan, suasana hati, kehendak, motivasi, keinginan dan kesanggupan untuk mendisiplinkan diri dan memahami diri sendiri. Orang yang mempunyai skor tinggi dalam faktor-faktor kecerdasan intrapersonal akan digambarkan sebagai seorang yang merasa nyaman pada dirinya sendiri, puas dan berpikiran positif karena apa yang dilakukannya itu atas jerih payahnya sendiri.

Untuk mengetahui lebih mendalam terkait dengan kecerdasan intrapersonal, Alder (Risa, 2013) menyatakan bahwa ada tiga aspek utama yang dapat dijadikan patokan untuk mengukur kecerdasan intrapersonal yaitu: (a) mengenali diri sendiri, (b) mengetahui apa yang diinginkan, dan (c) mengetahui apa yang penting.

Kecerdasan intrapersonal selama pembelajaran matematika ketika guru mendengar komentar siswa yang telah selesai mengerjakan soal ujian sekolah, yaitu: (1) "Wah! Jawaban soal No. 2 saya cuma benar setengahnya", (2) soal No. 5, saya salah menerapkan rumus!", (3) "Alhamdulillah, 4 soal benar semua kecuali soal no. 5, sangat susah!". Jadi, contoh 1, 2, dan 3 tersebut menunjukkan adanya pemahaman akan diri sendiri melalui kegiatan refleksi diri yang telah dilakukan oleh siswa terkait keyakinan dan kesalahan yang telah dilakukan dalam menjawab soal ujian. Kesalahan-kesalahan yang telah diungkapkan oleh siswa tersebut adalah acuan untuk lebih meningkatkan kemampuanya dalam pelajaran matematika. Contoh-contoh tersebut sejalan dengan pendapat Bondan (2012), bahwa kecerdasan intrapersonal berkaitan dengan kemampuan seseorang dalam hubungannya dengan kapasitas introspektif dan self-reflective. Mereka yang memiliki kecerdasan intrapersonal yang tinggi cenderung memiliki pemahaman yang mendalam tentang diri mereka sendiri, apa kekuatan atau kelemahan dirinya, dan apa yang membuat dirinya unik. Selain itu, diperkuat adanya penelitian yang relevan oleh 
Muhammad Hayatul Maki tahun 2012 dengan judul penelitian "Pengaruh Kecerdasan Intrapersonal, Media Pembelajaran Microsoft Mathematic Dan Motivasi Siswa Terhadap Prestasi Belajar Matematika Siswa Kelas VII SMP Terpadu Al-Anwar Durenan Tahun Ajaran 2011/2012" Dengan hasil penelitian yang diperoleh adalah ada pengaruh yang signifikan kecerdasan intrapersonal dengan prestasi belajar. Jadi, sangat jelas kecerdasan intrapersonal berpengaruh terhadap prestasi belajar matematika.

Kabupaten Polewali Mandar terdiri dari 9 Sekolah Menengah Atas Negeri yaitu SMA Negeri 1 Polewali, SMA Negeri 2 Polewali, SMA Negeri 2 Polewali, dan SMA Negeri 1 Wonomulyo dengan tingkat akreditasi A, SMA Negeri 4 Polewali, SMA Negeri 1 Campalagian, SMA Negeri 1 Tinambung, dan SMA Negeri 1 Alu yang berakreditasi B, serta SMA Negeri Matakali adalah sekolah yang tidak terakreditasi. Akreditasi tersebut merupakan penilaian yang dilakukan oleh Badan Akreditasi Nasional Sekolah (BAN-S/M) untuk menguji kelayakan suatu sekolah berdasarkan pada standar nasional yang telah ditentukan. Sekolah dengan akreditasi yang baik artinya mempunyai poin tertinggi dari tiap standar nasional yang telah ditetapkan dan tentunya akan mengahsilkan kualitas sumber daya manusia yaitu siswa yang unggul dengan berbagai prestasi.

Ada dua faktor yang berpengaruh terhadap prestasi belajar matematika yaitu faktor internal dan faktor eksternal. Faktor internal yaitu kecerdasan intrapersonal, sedangkan faktor internal yaitu terkait sarana prasarana, suasana belajar, dan lingkungan. Berdasarkan standar nasional, sarana dan prasarana termasuk dalam kategori penilaian ke lima dalam akreditasi suatu sekolah. Tercapainya prestasi belajar siswa yang maksimal dipengaruhi oleh dua faktor yaitu internal dan eksternal. kedua faktor tersebut saling mendukung satu sama lain dan menjadi acuan penting bagi guru untuk dapat meningkatkan prestasi belajar siswa khususnya matematika. Maka dari itu, penulis tertarik untuk melakukan penelitian mengenai pengaruh kecerdasan intrapersonal terhadap prestasi belajar matematika siswa ditinjau dari tingkat akreditasi sekolah SMA Negeri di Kabupaten Polewali Mandar.

Berdasarkan latar belakang tersebut, maka tujuan dari penelitian ini adalah: (1) untuk mendeskripsikan kecerdasan intrapersonal dan prestasi belajar matematika siswa SMA Negeri di Kabupaten Polewali Mandar ditinjau dari sekolah yang akreditasi A, B, dan tidak terakreditasi, (2) untuk menganalisis seberapa besar pengaruh kecerdasan intrapersonal terhadap 
prestasi belajar matematika siswa SMA Negeri di Kabupaten Polewali Mandar ditinjau dari sekolah yang akreditasi A, B, dan tidak terakreditasi.

\section{METODE PENELITIAN}

Penelitian ini menggunakan jenis penelitian kuantitatif yaitu ex-post facto. Penelitian ex-post facto dirancang untuk menerangkan adanya hubungan sebab akibat antar variabel dan menguji hipotesis yang telah dirumuskan sebelumnya antara kecerdasan intrapersonal dengan prestasi belajar matematika.

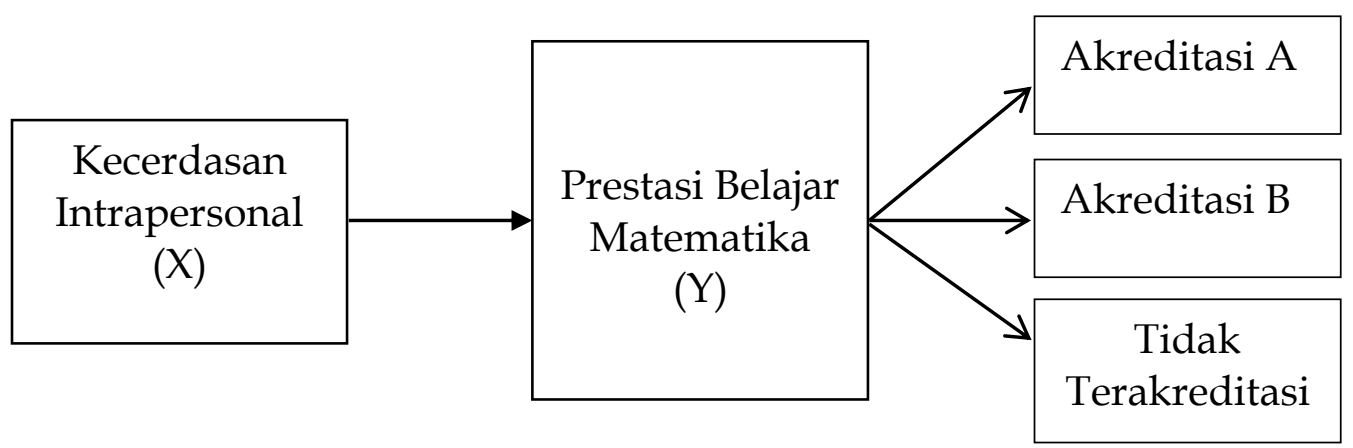

Gambar 1. Desain Hubungan antara Variabel Eksogen dan Variabel Endogen

Populasi dalam penelitian ini adalah seluruh siswa sekolah kelas XI MIPA SMA Negeri Kabupaten Polewali Mandar Tahun pelajaran 2016/2017. Berdasarkan data yang diperoleh dari layanan terpadu Kemdikbud diperoleh jumlah SMA Negeri sebanyak 9 sekolah.

Metode pengambilan sampel yang digunakan untuk memperoleh sampel acak dan dapat merepresentasikan karakteristik populasi adalah menggunakan teknik sampling acak bersrata proporsional (proporsional stratified random sampling). Teknik pengambilan sampel dilakukan melalui dua tahap. Pada pemilihan tahap pertama, menentukan sampel sekolah berdasarkan strata dari setiap sekolah SMA Negeri yang ada di Kabupaten Polewali Mandar secara acak, yaitu SMA Negeri 1 Polewali Mandar dan SMA Negeri 3 Polewali Mandar yang mewakili sekolah berakreditasi A, SMA Negeri 1 Tinambung yang mewakili sekolah yang berakreditasi B, dan SMA Negeri Matakali yang mewakili sekolah yang tidak terakreditasi. Pada tahap kedua menentukan kelas yang akan dijadikan subjek penelitian dengan mengambil 1 kelas masing-masing sekolah dan diperoleh sampel sebanyak 132 siswa. 
Adapun instrumen yang digunakan dalam penelitian ini berupa tes dan angket. Tes digunakan untuk memperoleh informasi mengenai prestasi belajar matematika, sedangkan angket digunakan untuk memperoleh informasi mengenai kecerdasan intrapersonal.

Tes yang dimaksud dalam penelitian ini adalah tes prestasi dalam bentuk pilihan ganda Untuk ukuran kisaran skor adalah 0 dan 1 pada tiap butir pertanyaan. Skor 0 bila responden menjawab salah dan skor 1 bila responden menjawab benar. Untuk mengukur variabel kecerdasan intrapersonal maka digunakan angket berupa pernyataan dari masing-masing indikator untuk tiap-tiap variabel yang diajukan kepada responden. Adapun ukuran yang digunakan dalam bentuk skala Likert. Alternatif jawaban pada skala kecerdasan intrapersonal terdiri dari Sangat Sesuai (SS), sesuai (S), Netral (N), tidak sesuai (TS) dan sangat tidak sesuai (STS). Pemberian skor pada skala ini adalah 1 sampai 5 pada tiap butir. Untuk pernyataan positif, skor 5 diberikan kepada jawaban sangat sesuai (SS), skor 4 jawaban sesuai (S), skor 3 jawaban Netral (N), skor 2 jawaban tidak sesuai (TS), dan skor 1 jawaban sangat tidak sesuai (STS). Untuk pernyataan negatif, skor 1 diberikan kepada jawaban sangat sesuai (SS), skor 2 jawaban setuju (S), skor 3 jawaban kurang sesuai (KS), skor 4 jawaban tidak sesuai (TS), dan skor 5 jawaban sangat tidak sesuai (STS).

Instrumen yang telah dirancang untuk mengukur variabel yang akan diteliti telah dilakukan uji validitas (kesahihan) yaitu validitas logis dan empiris setelah itu dilakukan uji reliabilitas (keandalan). Instrumen angket kecerdasan intrapersonal terdiri dari 36 item pernyataan dan yang valid adalah 23 item pernyataan dengan nilai Cronbach's Alpha sebesar 0,740. Instrumen tes prestasi belajar matematika terdiri dari 35 butir soal dan yang valid adalah 15 butir soal dengan nilai Cronbach's Alpha sebesar 0,742. Jadi kriteria koefisien korelasi validitas instrumen tersebut berada pada kategori tinggi dan dapat diterapkan pada penelitian.

Pengumpulan data dilakukan dengan memberikan instrumen kepada siswa yang telah memenuhi syarat valid dan reliabel. Pengumpulan data ini dilakukan secara bertahap pada bulan April sampai bulan Mei 2017. Data yang diperoleh dari pemberian instrumen kepada siswa akan dianalisis untuk menjawab hipotesis penelitian.

Analisis yang digunakan adalah statistika deskriptif dan statistika inferensial dengan bantuan perangkat statistik SPSS 20. Untuk tujuan (1) adalah dianalisis dengan menggunakan statistika deskriptif meliputi mean, 
median, variansi, skewness, kurtosis, minimum, maksimum dan tabel distribusi frekuensi. Untuk tujuan (2) adalah dianalisis dengan menggunakan model analisis regresi linear sederhana dengan bantuan perangkat statistik SPSS 20.

\section{HASIL PENELITIAN DAN PEMBAHASAN}

\section{Hasil Penelitian}

a. Variabel Kecerdasan Intrapersonal

Distribusi frekuensi skor kecerdasan intrapersonal siswa kelas XI MIPA berdasarkan tingkat akreditasi sekolah SMA Negeri di Kabupaten Polewali Mandar sebagai berikut:

Tabel 1. Distribusi Skor Kecerdasan Intrapersonal akreditasi A, B, dan Tidak Terakreditasi

\begin{tabular}{|c|c|c|c|c|c|c|c|c|}
\hline \multirow[b]{2}{*}{$\begin{array}{l}\mathbf{N} \\
\mathbf{o}\end{array}$} & \multirow[b]{2}{*}{ Skor } & \multicolumn{3}{|c|}{ Frekuensi } & \multicolumn{3}{|c|}{ Persentase (\%) } & \multirow[t]{2}{*}{ Kategori } \\
\hline & & A & B & $\begin{array}{c}\text { Tidak } \\
\text { Terkareditasi }\end{array}$ & A & B & $\begin{array}{c}\text { Tidak } \\
\text { Terkareditasi } \\
\end{array}$ & \\
\hline 1 & $23 \leq \mathrm{KI}<41$ & 0 & 0 & 0 & 0 & 0 & 0 & $\begin{array}{l}\text { Sangat } \\
\text { Rendah }\end{array}$ \\
\hline 2 & $41 \leq \mathrm{KI}<59$ & 0 & 0 & 0 & 0 & 0 & 0 & Rendah \\
\hline 3 & $59 \leq \mathrm{KI}<77$ & 10 & 1 & 1 & 13 & 3 & 4 & Sedang \\
\hline 4 & $77 \leq \mathrm{KI}<95$ & 62 & 22 & 18 & 81 & 67 & 82 & Tinggi \\
\hline 5 & $95 \leq \mathrm{KI} \leq 115$ & 5 & 10 & 3 & 6 & 30 & 14 & $\begin{array}{l}\text { Sangat } \\
\text { Tinggi }\end{array}$ \\
\hline & Jumlah & 77 & 33 & 22 & 100 & 100 & 100 & \\
\hline
\end{tabular}

Pada tabel 1 menunjukkan bahwa, untuk sekolah dengan akreditasi A, B, dan tidak terakreditasi, rata-rata siswanya memiliki kecerdasan intrapersonal yang tinggi yaitu di atas $70 \%$. Hasil tersebut menunjukkan bahwa siswa-siswa mempunyai kesadaran diri dan keyakinan yang kuat dalam meningkatkan kemampuan belajar matematika. selain itu, siswa yang memiliki kecerdasan intrapersonal dalam kategori sangat tinggi menunjukkan bahwa untuk sekolah dengan akreditasi A, ada 6\% siswa atau sekitar 5 siswa, untuk akreditasi $\mathrm{B}$, ada $30 \%$ atau sekitar 10 siswa, dan untuk sekolah yang tidak terakreditasi, ada $14 \%$ atau sekitar 3 siswa. Hasil tersebut menunjukkan bahwa siswa telah memenuhi semua indikator dalam kecerdasan intrapersonal yaitu mengenali diri sendiri, mengetahui apa yang diinginkan, dan mengetahui apa yang penting untuk dapat meraih prestasi. Sedangkan 
siswa yang memiliki kecerdasan intrapersonal dengan kategori rendah sangat sedikit yaitu untuk akreditasi A diperoleh sekitar $13 \%$ siswa atau sekitar 10 siswa, untuk akreditasi B hanya $3 \%$ atau sekitar 1 siswa, dan untuk sekolah yang tidak terakreditasi diperoleh $4 \%$ yang juga 1 siswa. Jadi, hasil tersebut menunjukkan bahwa siswa yang mempunyai kecerdasan intrapersonal pada kategori rendah, sangat kurang tingkat kesadaran dirinya dalam meningkatkan kemampuan di bidang studi matematika dan tidak memenuhi semua indikator dalam kecerdasan intrapersonal.

b. Variabel Prestasi Belajar Matematika

Distribusi frekuensi skor tes prestasi belajar matematika siswa kelas XI MIPA SMA Negeri di Kabupaten Polewali Mandar sebagai berikut:

Tabel 2. Distribusi Skor Tes Prestasi Belajar Matematika Akreditasi A, B, dan Tidak Terakreditasi

\begin{tabular}{|c|c|c|c|c|c|c|c|c|}
\hline \multirow{2}{*}{$\begin{array}{l}\mathbf{N} \\
\mathbf{o}\end{array}$} & \multirow[b]{2}{*}{ Skor } & \multicolumn{3}{|c|}{ Frekuensi } & \multicolumn{3}{|c|}{ Persentase (\%) } & \multirow[t]{2}{*}{ Kategori } \\
\hline & & A & B & $\begin{array}{c}\text { Tidak } \\
\text { Terkareditasi }\end{array}$ & A & B & $\begin{array}{c}\text { Tidak } \\
\text { Terkareditasi }\end{array}$ & \\
\hline 1 & $0 \leq \mathrm{KI}<56$ & 66 & 33 & 21 & 86 & 100 & 95 & Kurang \\
\hline 2 & $56 \leq \mathrm{KI}<71$ & 9 & 0 & 0 & 11 & 0 & 0 & Cukup \\
\hline 3 & $71 \leq \mathrm{KI}<86$ & 2 & 0 & 1 & 3 & 0 & 5 & Baik \\
\hline 4 & $77 \leq \mathrm{KI}<100$ & 0 & 0 & 0 & 0 & 0 & 0 & $\begin{array}{l}\text { Sangat } \\
\text { Baik }\end{array}$ \\
\hline & Jumlah & 77 & 33 & 22 & 100 & 100 & 100 & \\
\hline
\end{tabular}

Pada tabel 2 menunjukkan bahwa, untuk sekolah dengan akreditasi A, B, dan tidak terakreditasi, rata-rata siswa memperoleh nilai matematika yang termasuk dalam kategori kurang yaitu sekitar $90 \%$. Hasil tersebut memberikan informasi bahwa sebagian besar siswa kelas XI MIPA SMA Negeri di Kabupaten Polewali Mandar mempunyai kemampuan yang sangat rendah dalam pelajaran matematika. Jadi, dapat disimpulkan bahwa tidak ada perbedaan yang signifikan antara sekolah dengan akreditasi A, B, dan tidak terakreditasi dalam hal prestasi belajar matematika. Selain itu, siswa yang memiliki prestasi belajar matematika dengan kategori cukup menunjukkan bahwa untuk akreditasi A diperoleh $11 \%$ atau sekitar 9 siswa, sedangkan sekolah dengan akreditasi B dan tidak terakreditasi diperoleh $0 \%$ atau tidak ada siswa yang berada pada kategori cukup. Hasil ini menunjukkan bahwa hanya beberapa siswa yang lebih baik dibanding siswa yang memperoleh nilai kategori kurang. Demikian halnya untuk siswa yang memiliki prestasi belajar 
matematika dengan kategori baik, untuk akreditasi A diperoleh $3 \%$ atau sekitar 2 siswa, untuk akreditasi B diperoleh $0 \%$, dan untuk sekolah yang tidak terakreditasi yaitu 5\% atau sekitar 1 siswa. Jadi dapat disimpulkan bahwa sangat sedikit siswa yang mempunyai kemampuan matematika dengan kategori baik di Kelas XI MIPA SMA Negeri di kabupaten Polewali Mandar.

Data dari hasil penelitian telah memenuhi syarat uji prasyarat yaitu asumsi normalitas dan linearitas. Setelah itu dilakukan uji hipotesis.

1. Sekolah Akreditasi A (SMA Negeri 1 Polewali dan SMA Negeri 3 Polewali)

Hipotesis:

Ho : Kecerdasan intrapersonal tidak berpengaruh terhadap prestasi belajar matematika siswa kelas XI MIPA akreditasi A SMA Negeri di Kabupaten Polewali Mandar

Ha : Kecerdasan intrapersonal berpengaruh terhadap prestasi belajar matematika siswa kelas XI MIPA akreditasi A SMA Negeri di Kabupaten Polewali Mandar

Tabel 3. Koefisien $X$ terhadap $Y$

\begin{tabular}{|c|c|c|c|c|c|c|}
\hline & \multirow[t]{2}{*}{ Model } & \multicolumn{2}{|c|}{$\begin{array}{l}\text { Unstandardized } \\
\text { Coefficients }\end{array}$} & \multirow{2}{*}{$\begin{array}{c}\begin{array}{r}\text { Standardized } \\
\text { Coefficients }\end{array} \\
\text { Beta } \\
\end{array}$} & \multirow[t]{2}{*}{$\mathbf{t}$} & \multirow[t]{2}{*}{ Sig. } \\
\hline & & B & Std. Error & & & \\
\hline \multirow{2}{*}{1} & (Constan) & 57,083 & 25,504 & & 2,238 & ,028 \\
\hline & KI &,- 259 & ,301 &,- 099 &,- 862 & ,392 \\
\hline
\end{tabular}

Berdasarkan tabel 3 di atas, harga a yang diperoleh adalah 57,083 sedangkan harga $b=-0,259$. Dari harga a dan $b$, maka persamaan regresi yang dapat dibuat adalah $Y=57,083$ - 0,259X. Pada persamaan ini dapat diprediksi bahwa hasil belajar $(Y)$ rata-rata akan berubah sebesar -0,259 untuk setiap unit perubahan yang terjadi pada kecerdasan intrapersonal $(X)$. karena nilai koefisien regresi bernilai negatif (-), maka dengan demikian dapat dikatakan bahwa kecerdasan intrapersonal $(X)$ berpengaruh negatif terhadap prestasi belajar matematika (Y). Selanjutnya adalah melakukan uji hipotesis. Pada tabel 3. menunjukkan bahwa nilai signifikansi (sig.) sebesar 0,392 lebih besar dari > 0,05, sehingga dapat disimpulkan Ho diterima, yang berarti bahwa tidak ada 
pengaruh kecerdasan intrapersonal terhadap prestasi belajar matematika. Selain itu, dilakukan juga statistik uji $\mathrm{t}$, pada tabel 4.3 diperoleh nilai $t_{\text {hitung }}$ sebesar $-0,862$ pada taraf sifnifikansi $5 \%$ dibandingkan dengan $t_{\text {tabel }}(\mathrm{dk}=75)$ sebesar 1,992. Karena $t_{\text {hitung }}<t_{\text {tabel }}$ sehingga dapat disimpulkan bahwa Ho diterima yang artinya kecerdasan intrapersonal tidak berpengaruh terhadap prestasi belajar matematika pada sekolah akreditasi A.

2. Sekolah Akreditasi B (SMA Negeri 1 Tinambung)

Hipotesis:

Ho : Kecerdasan intrapersonal tidak berpengaruh terhadap prestasi belajar matematika siswa kelas XI MIPA akreditasi B SMA Negeri di Kabupaten Polewali Mandar

Ha : Kecerdasan intrapersonal berpengaruh terhadap prestasi belajar matematika siswa kelas XI MIPA akreditasi B SMA Negeri di Kabupaten Polewali Mandar

Tabel 4. Koefisien X terhadap Y

\begin{tabular}{|c|c|c|c|c|c|c|}
\hline & \multirow[t]{2}{*}{ Model } & \multicolumn{2}{|c|}{$\begin{array}{l}\text { Unstandardized } \\
\text { Coefficients }\end{array}$} & \multirow{2}{*}{$\begin{array}{c}\begin{array}{c}\text { Standardized } \\
\text { Coefficients }\end{array} \\
\text { Beta } \\
\end{array}$} & \multirow[t]{2}{*}{$\mathrm{T}$} & \multirow[t]{2}{*}{ Sig. } \\
\hline & & B & Std. Error & & & \\
\hline \multirow{2}{*}{1} & (Constant) & $-25,446$ & 23,981 & & $-1,061$ & 0,297 \\
\hline & KI & 0,513 & 0,263 & 0,331 & 1,952 & 0,060 \\
\hline
\end{tabular}

Berdasarkan tabel 4, harga $a$ yang diperoleh adalah -25,446 sedangkan harga $b=0,513$. Dari harga a dan $\mathrm{b}$, maka persamaan regresi yang dapat dibuat adalah $Y=-25,446+0,513 X$. Pada persamaan ini dapat diprediksi bahwa hasil belajar $(\mathrm{Y})$ rata-rata akan berubah sebesar 0,513 untuk setiap unit perubahan yang terjadi pada kecerdasan intrapersonal $(X)$. Selanjutnya adalah melakukan uji hipotesis. Pada tabel 4. menunjukkan bahwa nilai signifikansi (sig.) sebesar 0,06 lebih besar dari $>0,05$, sehingga dapat disimpulkan Ho diterima, yang berarti bahwa tidak ada pengaruh kecerdasan intrapersonal terhadap prestasi belajar matematika. Selain itu, dilakukan juga statistik uji $\mathrm{t}$, pada tabel 4.3 diperoleh nilai thitung sebesar 1,952 pada taraf sifnifikansi 5\% dibandingkan dengan $t_{\text {tabel }}(\mathrm{dk}=31)$ sebesar 2,039. Karena $t_{\text {hitung }}<t_{\text {tabel }}$ sehingga dapat disimpulkan bahwa Ho diterima yang artinya kecerdasan intrapersonal 
tidak berpengaruh terhadap prestasi belajar matematika pada sekolah akreditasi B.

3. Sekolah yang tidak terakreditasi (SMA Negeri Matakali)

Hipotesis:

Ho : Kecerdasan intrapersonal tidak berpengaruh terhadap prestasi belajar matematika siswa kelas XI MIPA SMA Negeri di Kabupaten Polewali Mandar

Ha : Kecerdasan intrapersonal berpengaruh terhadap prestasi belajar matematika siswa kelas XI MIPA SMA Negeri di Kabupaten Polewali Mandar

Tabel 5. Koefisien X terhadap Y

\begin{tabular}{|c|c|c|c|c|c|c|}
\hline & \multirow[t]{2}{*}{ Model } & \multicolumn{2}{|c|}{$\begin{array}{l}\text { Unstandardized } \\
\text { Coefficients }\end{array}$} & \multirow{2}{*}{$\begin{array}{c}\text { Standardized } \\
\text { Coefficients }\end{array}$} & \multirow[t]{2}{*}{$\mathbf{T}$} & \multirow[t]{2}{*}{ Sig. } \\
\hline & & B & Std. Error & & & \\
\hline \multirow{2}{*}{1} & (Constant) & 55,041 & 39,392 & & 1,397 & 178 \\
\hline & KI &,- 306 & 454 &,- 149 &,- 674 & ,508 \\
\hline
\end{tabular}

Berdasarkan tabel 5, harga $a$ yang diperoleh adalah 55,041 sedangkan harga $b=-0,306$. Dari harga a dan $\mathrm{b}$, maka persamaan regresi yang dapat dibuat adalah $Y=55,041-0,306 X$. Pada persamaan ini dapat diprediksi bahwa hasil belajar (Y) rata-rata akan berubah sebesar -0,306 untuk setiap unit perubahan yang terjadi pada kecerdasan intrapersonal $(X)$. karena nilai koefisien regresi bernilai negatif (-), maka dengan demikian dapat dikatakan bahwa kecerdasan intrapersonal $(X)$ berpengaruh negatif terhadap prestasi belajar matematika (Y). Selanjutnya adalah melakukan uji hipotesis. Pada tabel 5. menunjukkan bahwa nilai signifikansi (sig.) sebesar 0,508 lebih besar dari > 0,05, sehingga dapat disimpulkan Ho diterima, yang berarti bahwa tidak ada pengaruh kecerdasan intrapersonal terhadap prestasi belajar matematika. Selain itu, dilakukan juga statistik uji $\mathrm{t}$, pada tabel 4.5 diperoleh nilai $t_{\text {hitung }}$ sebesar $-0,674$ pada taraf sifnifikansi $5 \%$ dibandingkan dengan tabel $(\mathrm{dk}=20)$ sebesar 2,086. Karena $t_{\text {hitung }}<t_{\text {tabel }}$ sehingga dapat disimpulkan bahwa Ho diterima yang artinya kecerdasan intrapersonal tidak berpengaruh terhadap prestasi belajar matematika. 


\section{Pembahasan}

Dari hasil penelitian yang ditemukan di SMA Negeri Kabupaten Polewali Mandar pada sekolah yang mempunyai akreditasi A, B, dan tidak terakreditasi maka diperoleh kesimpulan bahwa kecerdasan intrapersonal tidak berpengaruh terhadap prestasi belajar matematika siswa disebabkan banyaknya faktor yang mempengaruhi prestasi belajar itu sendiri. Orang yang mempunyai skor tinggi dalam faktor-faktor kecerdasan intrapersonal akan digambarkan sebagai seorang yang merasa nyaman pada dirinya sendiri, puas dan berpikiran positif karena apa yang dilakukannya itu atas jerih payahnya sendiri. Berdasarkan penjelasan tersebut, menunjukkan bahwa siswa yang mempunyai kecerdasan intrapersonal mempunyai sikap yang mandiri dan percaya diri karena selalu berusaha berfikir positif dengan apapun keputusan yang telah ia lakukan. Oleh karena itu, ketika siswa yang memiliki kecerdasan intrapersonal yang tinggi mengerjakan tes prestasi belajar matematika, maka siswa tersebut yakin dengan jawaban yang ia pilih karena adanya rasa percaya diri yang kuat di dalam dirinya tanpa analisa lebih mendalam dengan kebenaran jawaban yang telah dipilih. Adapun hasil akhirnya yaitu berupa nilai prestasi belajar matematika yang tidak sesuai harapan, bukanlah suatu masalah besar bagi siswa yang mempunyai kecerdasan intrapersonal yang tinggi karena ia akan selalu melakukan refleksi diri dan berusaha untuk mendapatkan nilai yang lebih baik lagi dalam pelajaran matematika.

\section{SIMPULAN}

Berdasarkan hasil analisis data penelitian, maka kesimpulan dari penelitian ini adalah: (1) sekolah dengan akreditasi A diperoleh rata-rata skor kecerdasan intrapersonal sebesar 84,55 berada pada kategori tinggi dan prestasi belajar matematika dengan rata-rata skor 35,18 berada pada kategori kurang; untuk sekolah dengan akreditasi B diperoleh rata-rata skor kecerdasan intrapersonal sebesar 90,76 berada pada kategori tinggi dan prestasi belajar matematika dengan rata-rata skor 21,15 berada pada kategori kurang; untuk sekolah yang tidak terakreditasi diperoleh rata-rata skor kecerdasan intrapersonal sebesar 86,45 berada pada kategori tinggi dan prestasi belajar matematika dengan rata-rata skor 28,59 berada pada kategori kurang, (2) sekolah dengan akreditasi A diperoleh kesimpulan bahwa Kecerdasan Intrapersonal $(X)$ tidak berpengaruh terhadap prestasi belajar matematika siswa (Y) Kelas XI MIPA, Untuk akreditasi B diperoleh kesimpulan bahwa kecerdasan intrapersonal $(X)$ tidak berpengaruh terhadap 
prestasi belajar matematika siswa (Y) kelas XI MIPA, dan untuk sekolah yang tidak terakreditasi diperoleh kesimpulan bahwa kecerdasan intrapersonal $(X)$ tidak berpengaruh terhadap prestasi belajar matematika siswa (Y) Kelas XI MIPA. Kesimpulan tersebut menunjukkan bahwa fakta yang ditemukan dalam penelitian, tidak sesuai dengan teori dan penelitian sebelumnya yang menyatakan bahwa kecerdasan intrapersonal berpengaruh terhadap prestasi belajar matematika siswa. Oleh karena itu dapat dikatakan bahwa kecerdasan intrapersonal tidak berpengaruh terhadap prestasi belajar matematika siswa di kelas XI MIPA SMA Negeri di Kabupaten Polewali Mandar.

\section{DAFTAR PUSTAKA}

Angriani, A. D., Bernard, Nur, R., \& Nurjawahirah. (2016). Meningkatkan kemampuan pemecahan masalah melalui pembelajaran kooperatif think-talk-write pada peserta didik kelas VIII1 MTsN Model Makassar. MaPan : Jurnal Matematika dan Pembelajaran, 4 (1), 11-28.

Aryadi, H. (2008). Pengaruh kecerdasan intrapersonal terhadap prestasi belajar matematika ditinjau dari jenis kelamin siswa (Kelas XI SMA Negeri 1 Kecamatan Nogosari Kabupaten Boyolali). Skripsi. Universitas Muhammadiyah Surakarta.

Baharuddin \& Nur E. (2012). Teori belajar dan pembelajarannya. Yogyakarta: ArRuzz Media.

Bondan, D. W. (2012). Teori kecerdasan majemuk: Apa dan bagaimana mengaplikasikannya dalam pembelajaran matematika. Prosiding Seminar Nasional Penelitian, Pendidikan dan Penerapan MIPA. FMIPA Universitas Negeri Yogyakarta.

Hidayati, N., Mardiana, \& Riyadi. (2014). Eksperimentasi pembelajaran matematika dengan model pembelajaran kooperatif JIGSAW dan Teams Games Tournament (TGT) ditinjau dari kecerdasan intrapersonal siswa. Jurnal Elektronik Pembelajaran Matematika, 2 (2), 152162.

Lpdp. (2015). Daftar daerah tertinggal, terdepan dan terluar (perbatasan) tahun 2015. Jakarta: Lpdp Kementrian Keuangan Republik Indonesia.

Risa, H. (2013). Kecerdasan interpersonal pada siswa kelas IV SD Negeri Kembaran Kulon I. Skripsi. Universitas Negeri Yogyakarta. 
Wikandaru, A. (2011). Pengaruh kecerdasan intrapersonal dan prestasi belajar siswa terhadap keputusan penjurusan SMA Negeri 1 Kertasono Kabupaten Nganjuk. Skripsi. Universitas Negeri Malang. 